\title{
PERSONAL INFORMATION RIGHTS AND FREEDOMS WITHIN THE MODERN SOCIETY
}

\section{PRAVA I SLOBODE OSOBNIH PODATAKA U MODERNOM DRUŠTVU}

\section{Oleg Gennadievich Danilyan, Alexander Petrovich Dzeban, Yury Yurievich Kali- novsky, Eduard Anatolievich Kalnytskyi, Svetlana Borisovna Zhdanenko \\ Yaroslav Mudryi National Law University, Kharkiv, Ukraine Sveučilište Yaroslav Mudryi, Kharkiv, Ukrajina}

\begin{abstract}
The authors ascertain the correlation between the freedom of information use and both the freedom of speech and the right to information. There was applied the entire toolbox of interrelated and complementary universal scientific and specific methods inherent to philosophic research. The research methodology rests on the system and structure-functional analysis principles. The notions of information, freedom, justice and law are closely interlinked. When exercising freedom one inevitably makes his or her choice from among the available actions while relying on the previously obtained information. The human information rights that are, in their turn, a part of the overall notion of the law enjoy an exceptional role within the freedom of information. Far from being exhausted by the freedom of speech and the right to information, the freedom of information also includes various other aspects. It concerns the entire information and communication sphere at large. The freedom of information is not reduced to any certain type of socially-oriented information. The notion of the right to information goes beyond the right to access information while both of them take on the same social roles and are often terminologically interchangeable.
\end{abstract}

\section{Introduction}

The guarantees of human information rights and freedoms are among the essential principles forming the law-governed state and the civil society. These rights are also made part of a democracy's efficient state management mechan-
Sažetak

Autori utvrđuju povezanost između slobode korištenja informacija i slobode govora i prava na informiranje. Primijenjen je alat za međusobno povezane i komplementarne univerzalne znanstvene i specifične metode svojstvene filozofskom istraživanju. Metodologija istraživanja počiva na načelima sustava i strukturalnofunkcionalne analize. Pojmovi informiranja, slobode, pravde i zakona tijesno su međusobno povezani. Prilikom ostvarivanja slobode, neizbježan je izbor iz raspoloživih mjera, a oslanjajući se na prethodno dobivene informacije. Ljudska prava na informiranje koja su, zauzvrat, dio cjelokupnog pojma zakona, imaju iznimnu ulogu u slobodi informiranja. Daleko od iscrpljenosti slobodom govora i prava na informaciju, sloboda informiranja uključuje i razne druge aspekte. Radi se o cijeloj informacijskoj i komunikacijskoj sferi u cjelini. Sloboda informiranja se ne svodi na određenu vrstu društveno orijentiranih informacija. Pojam prava na informaciju nadilazi pravo na pristup informacijama, dok oboje imaju iste društvene uloge $i$ često su terminološki međusobno zamjenjivi.

ics. They touch upon the fundamental relationships between nationals and their governments, namely, the opportunities of criticising their governments, living according to their own convictions and seeking asylum from government repressions $/ \mathbf{1} /$. This makes ensuring the protection 
of human information rights and freedoms one of the information security's essential goals while a human becomes its centrepiece. Freedom is virtually the humanity's most precious value and achievement with centuries of bitter struggle to gain it. The term of "freedom" has quite a number of definitions. Some call freedom a possibility of easily overthrowing a tyrant; others, the right to elect someone to obey to; while the third say it is the right to carry arms and commit violence, etc. Thus, at a glance one gets the impression that freedom is a sort of construction material. Once you get it you can use it to create any shape or pattern in line with the modern trends and wishes. What actually happens is that the freedom arises and makes its place in the world via an invisible although clearly defined type of right, namely as law and order, responsibility, permissions and prohibitions as well as infringements. Naturally a human is a free being that initially enjoys the freedom of their activities and behaviour and has a free choice even with regard to their own life as he or she can choose between life and death. This means that freedom is inherent to him or her throughout the human existence. Hegel wrote that "a human reasonable to him or herself shall go beyond his or her boundaries by creating him or herself while going deeper inside to become intelligent to him or herself as well" /2/. Therefore, human life starts to make sense. Otherwise, why should one need any freedom of choice? The modern information society is based on information and communication technologies that have no separate existence without other social relationships and are constantly interacting with them. The human rights and freedoms also concern the information relationships that are directly linked to the society's democratisation which presupposes a greater role of the mass consciousness formed by the information. In view of the aforesaid, this article aims to ascertain the correlation between the freedom of information use and both the freedom of speech and the right to information given the rise of the information society.

\section{Methods}

Being theoretical this article uses the entire toolbox of interrelated and complementary universal scientific and specific methods inherent to philosophic research without prioritising any precise method. At the same time, the research methodology is based on philosophic reflection coupled with the universal scientific approaches and methods of researching the modern social processes. These include the empiric methods (allowing the research of information rights and freedoms phenomena in terms of external links and relationships) and the analytical and synthetic method (allowing the transformation of analytical judgments concerning the information rights and freedoms correlation into synthetic ones and the creation of an information base in order to state the findings). We also used the comparative method (allowing the comparison of the right to information and the right to access information as well as the freedom of speech and the right to information with a view to discover the common and different aspects of the said couples of phenomena) and the descriptive method (used to describe the characteristic features of manifestation of the information rights and freedoms and being a necessary precondition to formulate the findings). The research methodology rests on system and structure-functional analysis principles coupled with the historicity principle, thus making it possible to study the modern processes and phenomena in real-time mode and in the context of both the historical conditions of their development and the anthropological agenda.

2. The problems of Personal Information Rights and Freedoms in the modern scientific literature

Modern researchers of the freedom of speech tend to suppose that this issue in Europe dates back to the works by Spinoza who consistently discussed the freedom of both thought and speech. According to him, the freedom of speech is each person's natural right and may not be transferred to anyone. The freedom of speech may not only be granted without causing damage to virtue and peace, but it may not be cancelled as well without destroying virtue and peace $/ 3 /$. The growing significance of good balance between the right to information, the freedom of expression and the protection of confidentiality and personal data in the modern society is driven by dynamic and increasing large-scale involvement tools such as the Internet as well as the new paradigm bringing together the freedom of expression and the right to information $/ 4 /$. The present-day discussions focused on the human information rights and freedoms largely use the term of "freedom of information" as both interchangeable or having a special relationship with the right to information 
$/ 5 /, / 6 /, / 7 /, / 8 /, / 9 /$. This suggests special attention to distinguishing the said notions. By using the term of "freedom of information", the French researcher R. Pinto considers it a structural element to the freedom of speech $/ \mathbf{1 0} /$. In his view, the information is a unilateral process of transferring certain data from the informer to the recipient. Being an integral part of the freedom of speech the freedom of information has an impression of the latter's dual nature. That is, on the one hand, it includes the power to disseminate messages while, on the other hand, the power to freely obtain information. He suggests distinguishing the freedom of information from the right to information. One can hardly totally agree with such vision of correlation between the freedom of speech and the freedom of information. However, one can agree with R. Pinto distinguishing the active and passive aspects within the said set of information rights and freedoms that are inherent to almost each and every power to handle the information. The analysis of the communication rights and freedoms by the German researcher G. Gornig/11/ gives the idea that the right to information is nothing but a passive form of the freedom of information. He avoids using the term of the "right to information" on its own suggesting instead the use of the passive form of the freedom of speech although stating that these terms are identical. In his opinion, the freedom of speech is the active form of the freedom of information. G. Gornig distinguishes two aspects of the freedom of information: the freedom of speech and the right to information being equivalent to a certain extent as the latter includes the human perception of any information freely circulating within the society. M. Koren generally describes the freedom to communicate (that is the freedom of information) as each person's freedom to communicate with the others, to provide or receive information, that is to say, to send or receive communications $/ \mathbf{1 2} /$. Other elements that she distinguishes as part of the said freedom include the freedom of speech and the freedom to receive information. In this regard, the author rightfully insists that the legal framework for protecting the communication processes exactly plays the role of the freedom of information at large. She does not distinguish the right to information from among the freedom of information. However, she tacitly implies that it stands for the right to receive information while stating that the term is a misfit. A similar vision is shared by another Dutch re- searcher G. Schuijt /13/. However, he reduces the said definition of the freedom of information to solely the publicly available and socially circulated information. In this regard, it is characteristic that the author highlights two forms of the freedom of information including the personal freedom (each person's freedom to freely transfer and receive information through information exchange) and the institutional freedom of information pertaining to the media freedom. The latter includes the freedom of press (as its early manifestation), the freedom of broadcasting and the freedom of various other media. The protection mechanism for the institutional freedom of information encompasses the same aspects as those for the personal freedom. The freedom of seeking and receiving information as the mass media's essential activity element is of special importance for the institutional freedom of information. Such distinction has no material impact on the overall concept, but it proves to be extremely useful for the legal regulation of the said set of rights. Also worthy of mention is the position by the Dutch scientist J. de Meij based on an in-depth analysis of the research subject. He considers the state authorities' obligation to make public their documents and arguments in favour of their certain decisions as the cornerstone of a democratic society. He derives two wordings of the human rights based on such principle: the narrowly defined freedom of information which is the mass media's freedom to seek information; and a civil right to information, that is the freedom to receive information. Both freedoms when taken together are of importance for a person due to being the right to educate oneself and get to the bottom of every subject inviting his or her attention /14/. The American researcher C. Weeramantry also tends to consider the right to access information as a human's basic right. At the same time, he treats the term of the "right to information" as being equal to the right of access. Far from being distinguished in his interpretation these rights are easily replaced by a more general term of the "right to know". Therefore, the right to information only includes the power to receive information as its core element. It seems that such an interpretation considerably weakens the right to information by merely reducing it to the access to information. C. Weeramantry /15/ arrives at a conclusion that as the access to the relevant information is necessary in order to exercise various rights at every level the right to access the information constitutes in 
itself a human right. In his opinion, denying this would conflict with and make useless any specific major right. As stated by B. Voyenne, the right to information offers an efficient access to the sources ensuring the availability of social recipient for a traditional freedom of speech /16/. This right rests on the conviction that each person has the right to know for the simple reason that without such knowledge he or she is not a human being in its fullest sense. B. Voyenne uses the access to sources as a criterion to distinguish the right to information from the freedom of speech. In his opinion, the right to information serves as the "social copy" of the traditional freedom of speech and even conflicts with it to a certain extent. O. Hirvonen and J. Toivanen et al. suggest that the freedom of speech be understood as the social freedom and assert that the interpretation of the freedom of speech as the social freedom helps avoid various problems. Based on critical social theories by E. Fromm, C. Taylor and A. Honnet they try to assert their alternative tradition where the freedom ultimately harks back to the social relations and thus, demands respect to others /17/. Certain modern researchers advocate the revision of the "freedom of speech" as the "freedom of action" by reducing its protection to governing the relations in order to minimise the damage caused to the fundamental social values $/ \mathbf{1 8} /, / \mathbf{1 9} /$. When analysing the relevant views by the Russian scientists it must be noted that such categories as the right to information and the freedom of information were not quite popular. Many authors pay heed to them indirectly at the most, although a certain summary may still be provided. For instance, while developing the libertarian concept A. Stolyarov suggests that the information freedom phenomenon be regarded as the principle for the information exchange based on voluntary consent by all the participants directly involved therein with no obligations making such exchange impossible /20/. His interpretation of the term of "freedom of information" centres around the recognition of both the need for and the sufficiency of the common good will of all the participants directly involved in the information exchange in order to perform the same. He finds that any activity violating the personal freedom of information such as the transfer of information without the consent by at lease one of the participants to the information exchange (whether the one accepting or that providing the information) or the activities by the third persons hin- dering the voluntary information exchange constitute personal violence in the information field.

Thus, notwithstanding the above and certain other scientific works covering the said agenda the philosophic analysis of the personal information rights and freedoms lacks adequate attention by the contemporary world.

\section{Freedom as an Attribute of Human Ex-} istence

No one can exist outside the public life. Still, every individual enjoys certain freedom which drives the need for finding a common tool to measure the civic freedom providing a framework to ensure an individual's personal freedom. Such panhuman universal freedom that represents the social interests is actually formed under pressure and driven by the need. It becomes a commonly admissible freedom of all the individuals towards each other considering their common interest and is a benchmark for individuals to align themselves with while realising their personal interests within the society throughout their lifetime. Being universal the civic freedom actually coincides with the need represented by the standards, rules and laws. As stressed by Cicero, to be free a person shall be a slave to the law. There is no alternative here as no person may exist outside the public life, for in such case a person is not even aware of enjoying freedom (absolute by its nature). Personal freedom and the ways to exercise the same have been among the topical issues since the dawn of humanity. But the freedom itself is impossible without information as the information provides grounds for making a choice, while the possibility of choosing whatever is the essence of freedom. A tight relationship between the information, freedom, justice and law was noticed a great deal of time ago. Not coincidentally, the rules governing a person's information activities date back to as early as the $8^{\text {th }}$ century B.C. Further on, the development of social relationships and the technological advancements brought about the rapid development of the humanity's information sphere. A set of information rights was formed and the mass media came into existence. The information processes were firmly rooted in the social layer governed by the state. The new type of social community, namely, the information society used the technogenic development to create a new branch of law, i.e. the information law which finally led to forming a special human freedom being the information 
freedom $/ 21 /$. The presence of freedom in the modern world is a mandatory element of human existence. As a basic notion, the freedom may be subdivided into several elements such as the absolute freedom, the personal freedom and its subtypes. These include the information freedom, the freedom of artistic expression and the freedom of thought, etc. In particular, it was yet C. L. Montesquieu who distinguished the following types of freedom: "The philosophic freedom consists in an unimpeded expression of our will or at least (as stated by all the philosophic systems) in our conviction that we reveal it without hindrance. The political freedom involves our security or at least our confidence that we are secure" /22/. When exercising a freedom one makes his or her choice from among the available actions while relying on the previously obtained information. The need to choose between the absolute requirements is an indivertible feature of human life. The choice centres around the numerous and various pursuits that are competitive as to which ambition be prudent to choose and bring to life at a given moment. Every choice presupposes the freedom of action, that is the ability to do the things we choose. However, even where there is the right to choose and the freedom of action the sense of freedom also brings the feeling of unfreedom. A person making his or her choice seeks to not only accomplish his or her conflicting desires. So, the impossibility of concurrently realising all of them is perceived thereby as a violation of personal freedom. A free choice always has its distinct boundaries. Therefore, when making any free decisions an individual is still limited to a certain extent. When making a choice the good knowledge of the chosen options is of major importance. The information freedom has certain distinctive features. Firstly, building an individual's consciousness as his or her freedom's key element is one of the essential functions of the information freedom. An individual realises and directs his or her activities while perceiving him of herself as its source and exercising influence towards the object or confronting it. The wilful contraposition turns a person into a subject having its own personality, an inimitable "ego". Guided by interaction and communication processes, an individual gains and develops selfconsciousness used thereby to perceive the social principles, to behave in a certain way, to assess his or her self and the persons contacting him or her. Secondly, the availability of multiple information sources is a mandatory feature of the information freedom. This means that a person needs access to several information makers and distributors who are in a position to provide him or her with diversified information so that he or she can enjoy the freedom of information. By summarising such information a person opts for certain actions, thus exercising his or her freedom. Thirdly, an individual's ability to further retransfer the information is also characteristic of the freedom of information. A person shall be capable of transferring the information to any subjects. At the same time, when transferring and receiving the information one shall consider that the subjects being sources of information and those being its recipients also enjoy certain freedoms which shall be observed. Fourthly, the peculiarity of the freedom of information is that a substantial part of the social relationships may not be reproduced using rules of law. The regulation of information processes taking place between a person and the state as well as between a person and a social entity is quite practicable. At the same time, the daily information processes such as the information exchange covering family issues and hobnobs, etc. are much harder to control. The law may lay down the common principles of each one's activities, although no specific application thereof may be provided for each and every situation. In such cases, every person shall act proceeding from the common principles of law, freedom, morals and customs. This life facet can hardly be controlled by the state as any judgments by state officials that are based on quite vague regulatory wordings are capable of violating a person's freedom. Fifthly, the freedom of information shall be reflected in the information rights, but to no lesser extent shall it be expressed in the social morals and customs. In such a case, the morals regulate the personal behaviour while being a regulator that requires no public authorities. Morals are used as a criterion for a value-based outlook and serve as a means of harmonising the society's attitude towards a person. As one of the ways people realise their social relationships the morals pertain to both the consciousness and the reality. The information freedom's special magnitude consists in its symbiotic relationship with the natural law. The freedom of information provides certain opportunities that result from a person's natural condition, that of being free. The said opportunities being independent of the state's will are derived not from the state but the human na- 
ture itself. The state may not grant a possibility of exercising the freedom of information. It may not deprive of it either. It shall use the rules of law to ensure the conditions for an individual to exercise his or her freedom of information. The personal information rights that are, in their turn, a part of the overall notion of the law play an exceptional role in the freedom of information.

\section{Information Freedom and Rights}

By joining in a symbiotic relationship the due and potential behaviour as well as the unity and equality of the mutual rights and obligations the law manifests itself as a positive reality of the freedom that precludes the arbitrary rule, abuse of discretion and social oppression while delimiting the boundaries of freedom $/ 23 /$. The law is a tool that, using special methods of law, enables a person to exercise its freedom of information. Being the emanation of the society as a whole and resulting from its natural development the law shall take account of the interests of both the entire society and a certain individual. The law provides a human with certain opportunities to exercise his or her inherent freedom of information. The information rights may not be singled out into a certain group due to being used by individuals across all the facets of life at various stages which stresses the importance of the information rights and their considerable role in everyone's life. Apart from the rights directly used to exercise the freedom of information there are also the "neighbouring rights" encompassing an entire set of rights that contribute to the exercise of both a wide variety of rights and freedoms and an individual's freedom of information and his or her information rights. These include the right to petition, to recourse to state authorities, to enjoy the media freedom and to receive information as to the environmental status, etc. The information rights are no duplication of the same and correlate as universals and particulars. This means that the information rights govern the information processes in the fields non-governed by any other rights covering the information. Although being organically part of the other rights and freedoms the information rights streamline the information processes.The freedom of information determines the combination of certain natural law facilities and information rights. So, one should speak of precisely the freedom of information in the contemporary world and it should be used to research and interpret the human information
rights.The exercise of the freedom of information is one of the modern society's crucial tasks. By exercising the same an individual gets the information as to the various physical and ideal world objects while also exchanging the information with various objects and, thus creating new information. The receipt of the object-related information and the transfer of information occur in concert with the information carriers that may either have the information as to a single object at their disposal or accumulate the information relating to a variety of objects and transform the same. Certain limitations of the personal freedom of information are provided at an international level. Thus, Article 29 of the Universal Declaration of Human Rights reads as follows /24/:

1. Everyone has duties to the community in which alone the free and full development of his personality is possible.

2. In the exercise of his rights and freedoms, everyone shall be subject only to such limitations as are determined by law solely for the purpose of securing due recognition and respect for the rights and freedoms of others and of meeting the just requirements of morality, public order and the general welfare in a democratic society.

3. These rights and freedoms may in no case be exercised contrary to the purposes and principles of the United Nations.

Therefore, a person's freedom of information extends up to certain limits beyond which a person starts to violate the rights and freedoms of the others through his or her actions. The society's biggest challenge is to determine the precise boundaries for a person to use its freedom. The International Covenant on Civil and Political Rights also sets certain limits relating to the freedom of information, in particular its Article 19: "Everyone shall have the right to freedom of expression; this right shall include freedom to seek, receive and impart information and ideas of all kinds, regardless of frontiers, either orally, in writing or in print, in the form of art, or through any other media of his choice. The exercise of the said rights carries with it special personal duties and responsibilities. It may be subject to certain restrictions, but these shall only be such as are provided by law and are necessary: a) for respect of the rights or reputations of others; and b) for the protection of national security or of public order, or of public health or morals" /25/. In its turn, Article 10 of the European Convention for the Protection of Human Rights and Fundamental 
Freedoms provides a limitation as to a person's freedom of information, namely: "The exercise of these freedoms (in particular, the freedom of information), since it carries with it duties and responsibilities, may be subject to such formalities, conditions, restrictions or penalties as are prescribed by law and are necessary in a democratic society, in the interests of national security, territorial integrity or public safety, for the prevention of disorder or crime, for the protection of health or morals, for the protection of the reputation or rights of others, for preventing the disclosure of information received in confidence, or for maintaining the authority and impartiality of the judiciary" /26/. Many countries, especially those with traces of totalitarianism, put forward the means of protecting the freedom of information against the state rather than using the state. In such case, the monitoring of state activities shall be undertaken using the supranational bodies being generally beyond the will of the state and its economy and political landscape.

\section{Freedom of a Person and the Right to In-}

\section{formation}

Given the current active development and formulation of the conceptual framework of the right to information, there exist no similar approaches to determine its essence. However, much attention is paid to the correlation between the right to information and the other civic information rights and freedoms. This also largely determines the choice of terminology used to define this concept. Therefore, we suggest that the interrelation between the right to information and the related notions be regarded so as to better define the phenomena in question. The correlation between the right to information and the freedom of speech being somewhat a forerunner to the former is of utmost interest. Historically, the right to information stems from the freedom of speech. Moreover, the existing constitutional provisions of many countries concerning the freedom of speech highlight the relatively new right to information which was not intended to be there when laying down the constitutional groundwork. Generally, and quite understandably, the legal regulation of the information rights and freedoms across various countries has its own distinctive features. For this reason, the attitude that the freedom of speech encompasses the right to information has wide-spread occurrence. There are serious grounds to oppose to the inclusion of the right to information into the freedom of speech and press as this depletes its content. The receipt of information is just a single element of the narrow right to access the information while the right to information absorbs the freedom of speech and press mainly governing the dissemination of information. In our opinion, apart from being neither absorbed by the freedom of speech nor one of its elements the right to information conflicts with the same to a certain extent. First of all, it presupposes the right to impartial information as to what happens in the social life while the freedom of speech is aimed at free circulation of the evaluative information, opinions and positions of certain subjects.

Another important criterion for distinguishing the right to information from the freedom of speech is the efficient access to the sources of information. The latter is irrelevant for exercising the freedom of speech and sharing social visions while the right to information will be substantially violated in case of impossibility to obtain the significant details by every member of the community. Besides, the right to information and the freedom of speech have different social functions. While the freedom of speech ensures the free discussion of social issues the right to information is used by the civil society to interact with the state, attracts new portions of information through public discourse and disciplines public entities. A person's right to information sets the most common social options of using the information. First of all, it manifests itself in connection with the freedom being the overall feature of the human rights and is a measure and content of freedom which is the essence of all rights. The human rights provide the measurement and content to the notion of freedom. Accordingly, the efficient mechanism for exercising the right to information directly ensures the human freedom of information. Fundamentally, the human rights and freedoms are understood to be a limitation of the state authority and the scope of freedom is determined by the degree of individual autonomy. The boundaries of freedom are much wider than the extent of human rights. The entire system of civil information rights and freedoms shall be united in the notion of the "freedom of information" which covers the freedom of speech and expression, the freedom of press and mass media, the right to seek, receive, produce, keep, impart and transfer information. It also may include the civic right to public response and refutation of inaccurate in- 
formation, to the protection of the information sources, to the prohibition of censoring and other civic information rights.

As a legal doctrine, the freedom of information is a set of legal provisions that govern the social relationships providing the guaranteed opportunities of applying personal efforts across a wide range of social life facets by partaking in the information processes and of satisfying a person's material and spiritual needs. The freedom presupposes a person's selective and purposeful activity given the objective political, economic and legal framework. The freedom of information contributes to an individual's personal fulfilment and the omnidirectional development of his or her inclinations and talents as well as the realisation of personal needs. This freedom of information is distinguished by its special features: the free use of information, non-interference with a person's individual information activities which are beyond the obligations to the society or the state. The state interference with a person's spiritual activity shall be limited as this field is a unity of the reason, feeling and will manifestations. Therefore, the reliable guarantees of protection against the state and the officials hindering the exercise of the personal freedom of information are of utmost importance. We incline to the opinion that as a fundamental right the freedom of speech and the freedom of information ensure the protection from arbitrary interference by the state with the primary fields of human activity /12/. While critically reviewing the above findings we would like to highlight that the digital era becomes dependent on the cyber space with this dependency having an impact on the human freedom generally and the freedom of information specifically. The freedom of choice is especially limited by the available information and, more precisely, the one at our disposal which serves to make the choice. Due to the development of the Internet and the ebusiness in the age of cloud-based computing, the commercialisation of personal data becomes inevitable. Therefore, the protection of the traditional right to personal and information privacy becomes extremely topical given the modern conditions. It should be specifically highlighted that a person's freedom of information is not absolute. The law of every state and the society's generally accepted value system suggest their own ways to limit a person's freedom of information.

Besides, it is impossible to definitely determine the potential level of freedom. Its admissible de- gree is influenced by the international and domestic law, the national set of mind, the cultural and educational level, etc.

\section{Conclusions}

Considering the above the conclusions that offer themselves are as follows. Due to the breadth and polysemy of the very concept of information the essence of the term of "personal freedom" and the notion of the freedom of information tend to be unusually universal. Indeed, the boundaries of those freedoms are hard to set. They generally relate to the society's information field and serve as a guarantee to an individual's informational autonomy and self-determination. Notwithstanding the absence of any clear limits of the freedom of information its content is quite unambiguous and is represented by a set of precise rights and historically traditional personal freedoms. The essential role here surely belongs to the traditional freedom of speech and expression and the currently emerging right to information. They may be placed at different poles of the freedom of information which is explained by the different scope of their legal regulation. The freedom of speech is generally based on the derivative information and the evaluation categories while the right to information includes as part of its legal regulation scope the access to state resources and familiarisation with the socially significant information $/ 27 /$. However, in reality, they are hard to distinguish due to being often closely interrelated and serving as a precondition to one another. Following an analysis of interrelation between the freedom of information, on the one hand, and the freedom of speech and the right to information, on the other, we arrive at a finding that the right to information and the freedom of speech are the two separate elements of a much wider notion of the freedom of information. This statement is based on the concept of information that not only provides the evaluative data as well as someone's opinion or position, but also other factual data and non-biased details. Far from being exhausted by the freedom of speech and the right to information, the freedom of information also includes other kinds of individuals' information competencies within the society. These include, in particular, the freedom of mass information which is quite intrinsically precise and pertains to the mass media domain. This freedom generally concerns the entire sphere of communication and information circulation within the society. 
The freedom of information is not reduced to any certain type of socially-oriented information. It is fair to assume that the boundaries of the freedom of information are still expanding with the development of the information society and the rise of the information civilisation. The freedom of information is constrained by the limits of the precise rights and freedoms governed by the law and forming the content of the freedom of information. The issue of correlation between the right to information and the right to access information shall be given special attention. It is quite often that the first one is persistently replaced with the other. So, we would like to stress that the right to access information is part of a much broader constitutional right to information including (apart from the rights to seek and receive) the right to transfer, produce and disseminate the information. By its nature the right to access is a guarantee to the exercise of the broad right to information. However, both of them take on the same social roles and are often terminologically interchangeable. This is justified as the criterion for distinguishing them is quite insignificant and defines no major differences. Apparently, it would make sense if those concepts be considered to correlate as universal and particular. By ensuring the possibility of reviewing the official documents the right to access information guarantees the exercise of the universal right to information.Therefore, the human freedom of information and the set of legal regulations governing the same require an all-round philosophic insight and comprehension. In this connection it seems reasonable to consider that due to its extreme importance and topicality the agenda of interrelation and interaction between the information rights and freedoms opens new horizons for further research effort in the special sciences (law, sociology, theory of state and law) and through philosophic generalisation. Besides, the stated agenda shall concern the practical field as well including the law-making activities (at nationwide level) and those of the local authorities as well as drafting the inter-state (international) level documents.

\section{Notes}

/1/ C. Crabtree, M.J. Nelson (2017), New Evidence for a Positive Relationship between De Facto Judicial Independence and State Respect for Empowerment
Rights. International Studies Quarterly, Vol. 61, Iss. 1, pp. 210-224.

/2/ G.W.F. Hegel, (1990), The Philosophy of Law, ArtLit Publishers, Moscow, p.77.

/3/ Q. Huang (2017), Spinoza on Freedom of Speech and Its Limits. Universitas-Montly Review of Philosophy and Culture, Vol. 44, Iss. 8, pp. 23-38.

/4/ S.Toscano, (2017), Freedom of Expression, Right to Information, Personal Data and the Internet in the view of the Inter-American System of Human Rights. Adcaij-Advancts in distributed computing and artifical intelligence journal, Vol. 6, Iss. 1, pp. 21-29.

/5/ F. Ekardt; A. Hyla (2017), Human Rights, the Right to Food, Legal Philosophy, and General Principles of International Law. Archiv für Rechts-und Sozialphilosphie, Vol. 103, Number 2, pp. 221-238.

/6/ A. Gargano, A.G. Rossi, R. Wermers (2017), The Freedom of Information Act and the Race toward Information Acquisition. Review of Financial studies, Vol. 30, Iss. 6, pp. 2179-2228.

/7/ D.E. Pozen (2017), The Freedom of information beyong the freedom of Information act, University of Pennsylvania law review, Vol. 165, Iss. 5, pp. 10971158.

/8/ A. Saez-Martin; C. Caba-Perez; A. LopezHernandez (2017). Freedom of information in local government: rhetoric or reality? Local Government Studies, Vol. 43, Iss. 2, pp. 245-273.

19/ M.C. Stosic (2015), Freedom of Information and the Library. Qualitative \& Quantitative methods in libraries, pp. 883-889.

/10/ R. Pinto, (1955), La liberie d'opinion et d'information. Controle jurisdictiormel et controle administrtif, Montchrestien, Domat.

/11/ G-H. Gornig, (1955). Auperangsfreiheit und Informationsfreiheit als Menschenrechte, available at: http://books.google.com.ua/ (accessed October 2, 2017).

/12/ M. Koren, (1996), Tell me! The right of the child to information, thesis. Available at: http://dare.uva.nl/search?arno.record.id=20118 (accessed October 2, 2017).

/13/ G. Schuijt (1987), Werkers van het woord. Media en arbeidsverhoudingen in de journalistiek, Kluwer, Deventer.

/14/ J. de. Meij (1971), Wat is toch vrijheid van nieuwsgaring? In: Selectiviteit in de massacommunicatie, Deventer, Kluwer.

/15/ C.G. Weeramantry (1971), Access to information: a new human right. The right to know. Available at: https://books.google.com.ua/books?id=1rukxE8XG MgC\&pg=PA99\&lpg=PA99\&dq=Access+to+informa tion:+a+new+human+right.+The+right+to+know\&so ur-

ce=bl\&ots=JBfjR9Tpkm\&sig=iMvHK47LTGcar0Oge zmRnmsQBOc\&hl=ru\&sa=X\&ved=0ahUKEwjAxOXMqtL WAhUhOsAKHav- 
Oleg Gennadievich Danilyan, Alexander Petrovich Dzeban, Yury Yurievich Kalinovsky, Eduard Anatolievich Kalnytskyi, Svetlana Borisovna Zhdanenko: PERSONAL INFORMATION RIGHTS AND FREEDOMS WITHIN THE MODERN SOCIETY Informatol. 51, 2018., 1-2, 24-33

KDVQQ6AEIKjAA\#v=onepage\&q=Access $\% 20$ to $\% 20$ infor-

mation\%3A\%20a\%20new\%20human\%20right.\%20T he $\% 20$ right $\% 20$ to $\% 20 \mathrm{know} \& \mathrm{f}=$ false (accessed October 2, 2017).

/16/ B. Voyenne (1970), Le droit à l'information. AubierMontaigne, Paris.

/17/ J. Hietalahti; O. Hirvonen; J. Toivanen (2016), Insults, humour and freedom of speech. French cultural studies, Vol. 27, Iss. 3, (SI), pp. 245-255.

/18/ B. Leiter (2016), The Case against Free Speech. Sydney law review, Vol. 38, issue 4, pp. 407-439.

/19/ H. Parens (2016), Free Speech: A Right for Good and for Trouble-Making? International journal of applied psychoanalytic studies, Vol. 13, Iss. 3, pp. 200212.

/20/ A. V. Stolyarov (2012), Information Freedom and Information Violence, Synopsis of Ph. D. in Philosophy Dissertation, Lomonosov Moscow State University, Moscow.

/21/ O. Yetkinel; M. Colak, (2017), The Effects of Transformation of Public Sphere with the New Media in Academy. Eurasia journal of mathematics science and technology education, Vol. 13, Iss. 8, pp. 5009-5018.
/22/ C.-L. Montesquieu (1999), The Spirit of the Laws, Mysl Publishers, Moscow, p.122.

/23/ R. Zhao; B. Fu; H. Zhang (2016), Analysis on the Legal Regulation of Personal Information Commercialization in the Era of Cloud Computing. Proceedings of the 3D International conference on applied social science research, Vol. 105, pp. 76-79.

/24/ Universal Declaration of Human Rights (1948). Available

at: http://www.un.org/ru/documents/udhr/ (accessed October 1, 2017).

/25/ International Covenant on Civil and Political Rights (1966). Available at: http://www.un.org/ru/documents/decl_conv/conve ntions/pactpol.shtml (accessed October 1, 2017).

/26/ European Convention for the Protection of Human Rights and Fundamental Freedoms (1950). Available at: www.memo.ru/prawo/euro/eucnv.htm_(accessed October 2, 2017).

/27/ R. Rumbul (2016), Tools for transparency? Institutional barriers to effective civic technology in Latin America. 6th International Conference on E-Democracy and Open Government (CeDEM), Proceedings, pp. 147-155 